\title{
Global Language: Status, Scope and Challenges
}

\author{
- Lal Bahadur Bohara
}

\begin{abstract}
The world becomes shareable, narrow, familiar, and accessible for all since we have a common language (English) despite having culture, tradition, territory and idiosyncratic variation. Because of its commonness, it is accepted as an international, global, foreign/ second language or as a lingua-franca among thousands of diverse language speakers. It becomes the global language since its form is cozily perceptible and scope is being open-ended in nature. Having its scope unlimited, the status is automatically broadened and the positional value will be transformable from fewer to more, lesser-users to frequent, foreign to second language, etc. As the status and scope of English growing up, the opportunities and challenges have been raised as well. In the forms of opportunities, people are liable to get better jobs, quality education, and international identity and so on. In contrary, challenges oppose the regular development of it which may result minimizing the status and scope sooner than later. Whatever the situation, English language is stepping forward rather than pushing back.
\end{abstract}

Key words: English Language, Global, Scope, and Challenges

\section{Background}

As I was studying in pre-primary level, my schooling was in my mother tongue, though Nepali language was prescribed as a medium of instruction in the classroom. Now I can reflect the prevalent situation of my past about how it was and why. The reason behind this was the poor background of the teachers, infancy of students and rurality of the school positioning. From my early schooling, I was fond of uttering English alphabets rather than Nepali language. In return, my GURU JI used to thank and motivate me to do same frequently, which led me towards ascending success as I was climbing up the level of my schooling. During my schooling, it was the lively experience that higher the level lowers the proficiency in major compulsory subjects because of the lack of proficient teachers. Whatever the situation, I did not loss my temper and went on with the theme of 'where there is will there is the way' and a thematic expression " 


\section{Global Language: Status, Scope and Challenges}

if you speak English you will understand the whole world'. No sooner than later, I joined in majoring English and up to now I am following the same path being as a learner. A language is the means of communication and it exercises socialization, cultural transmission, sharing knowledge, power and politics, status and so on. Though various communication systems are there, human communication occupies uniqueness i.e. arbitrariness, voluntary-vocal, duality of patterning, displacement, etc. All the languages are different with respect to their scope, influence, status, standardization, popularity, commonness, dictions, culture, aspects, accents and extra-linguistic features as well. English is one of the most spoken languages in the world. So it is known as the international language as well.

English language has it long history of development. As the British colonized the different countries (most of the Asian, African and Latin American), they got chances to disseminate their language and culture throughout their colonies. Later on, the colonies were habituated to use it as their official language even after they got independency. In the rest world, it becomes their compulsion to use it as a foreign language since they have no any alternative to connect across the countries. As its scope has been growing up, more people use it around the world. Because of its flattened horizon, it is accepted as an international language and the global one.Regarding the nature of global language, Crystal (2003) states that a language achieves a genuinely global status when it develops a special role that is recognized in every country. English language has the same status in every country in the world. On the basis of the way the world wide nations plan in their own and people use it, there are native and non-native speakers. The non-native speakers are also categorized into second and foreign ones.

\section{English as a Global Language: Status}

A language which is globally recognized, understood, and having its users scattered everywhere is known as the global language. In favor of the status of English language, British Council views that English is now spoken by a quarter of the world's population, enabling a true single market in knowledge and ideas. Non-native speakers now substantially outnumber native speakers and as result, English increasingly belongs to the world rather than to any one country. Since its history, its craze has been increasing continuously. English language has been recorded as the global language since it has been used in different fields like; education, science, commerce, business, politics, diplomacy economics, tourism, trade, space study, media, net-internet, computer, bilateral-multilateral visits and summits and so on. In regards of global language, Crystal (2003) says that English is the language that has spread throughout the world most extensively and is dominating in a number of important fields including international commerce, education, and communication. In the linguistic globe, on the basis of its users and way the use, it can be classified into various forms. 


\section{English as a Native/First Language}

Those who use it by birth as their parents do are the first or native speakers. Native speakers are identified by observing their accent, way of pronunciation, extra-linguistic features, and cultural aspects and sometimes by their complexion as well. As Kachru cited in Crystal (2003), speakers of English from inner circle (USA, UK, Ireland, Canada, Australia and New Zealand) are the primary speakers of English. They are also known as the native speakers. According to Crystal (2003), the estimation shows that about 320-380 million people (inner circle) use it as native language around the world. But,as the English language becomes globalized, there is the great debate about whether the segregation should be done or not. As prof. Awasthi said [in his speech on: Trends and Issues in ELT in the world (Central NELTA program on $11^{\text {th }}$ of June, 2016)], there should not be the segregation among the English speakers by different terminologies, since it is accepted as an international and lingua-franca all over the world by all.

\section{English as a Second Language}

Most of the people use English as a second language as well. Regarding English as a second language Kachru as cited in Crystal (2003) views, the outer circleinvolves the earlier phases of the spread of English in non-native settings, where the language has become part of a country's chief institutions, and plays an important 'second language' role in a multilingual setting: it includes Singapore, India, Malawi and over fifty other territories. According to this view, it becomes clear that as it is used as an official language or the language of education, media, politics and so on, it is termed as the second language. Regarding the same status of English, Broughton, Brumfit, Flavell, Hill and Pincas (1980) quote as,

In a second language situation, English is the language of the mass media: newspapers, radio, and television are largely English media. English is also the language of official institutions- of Law courts, local and central government and of education. It is also the language of large commercial and industrial organizations (p. 6).

As a second language, numbers of speakers are there and governments give the permission as an official language. As Crystal mentions there are 300-500 million people (outer circle) use English as a second language. This rate has been growing up regularly.

\section{English as a Foreign Language}

English as a second and Foreign language have some features common but not as whole. As English is not used as an official language but as means of communication, instruction, tourism, journalism, etc, in such situation, it is termed as the foreign language. Regarding English as a foreign language, West (1953) as cited in, Broughton, Brumfit, Flavell, Hill and Pincas (1980) 


\section{Global Language: Status, Scope and Challenges}

states "the foreigner is learning English to express ideas rather than emotion: for his emotional expression he has the mother tongue...... it is a useful general rule that intensive words and items are of secondary importance to a foreign learners, however common they may be" (p.8). From this statement, it is understood that its foreign status is more communication based rather than official. As Kachru as cited in Crystal (2003) clarifies:

The expanding circle involves those nations which recognize the importance of English as an international language, though they do not have a history of colonization by members of the inner circle, nor have they given English any special administrative status. It includes China, Japan, Greece, Poland and (as the name of this circle suggests) a steadily increasing number of other states (p.10).

The expanding circle consists of other than natives and second language speakers, which are largest in numbers and increasing continuously. As Crystal presented, there are more than 5001000 million people (expanding circle) who use English as a foreign language.

The world status of English language depicts that it has already established as second, foreign, international, lingua-franca, and global language, what has to be done is retained the same and expands its horizon moreup to access of all human beings.

\section{English as a Global Language: Scope}

As anything has high coverage, scope and influence, it provides opportunities and hopes to its users obviously. So does the English language to its users earlier, sooner or later. As there is awell known saying that the one who has language to speak can sell the flour faster than the other who has to sell rice but no language. Same is the case in the English language use. One who has the better competence and performance in English language can be the citizen of the world and do have the better chances of living, trekking, studying, employment, trading, mutual friendship and socialization across and around the world. Euromonitor International (a research on the benefits of English language for individuals and societies) Report (2010) emphasizes;

Most companies interviewed said that staffs with English language skills had a strong advantage over other employees. For each of the five researched countries, around two-thirds of interviewees stated that employee with English language skills progress more quickly within the company and that English is beneficial for company growth (p. 8).

The report shows that having English language with working staffs is helpful to perform the targeted tasks easily. Likewise, those students who have the access of TOEFL, IELTS, GRE and so on, they can apply for hundreds of worldwide universities for their higher studies. The 
British Council has around 400 IELTS centers around the world and thousands of students get access to study abroad per year. One and all can be benefited by perceiving the worldwide opportunities and be able to exchange their own views, ideas, and necessities orally or in written forms so that out of your context could know who you are and you yourself could know who others are. Some of the possible areas of scope of English language are as:

\section{English in Business}

Most of the people are involved in business. English is being the lingua-franca, people do give and take in it. It is the most important means of business in border areas. Graddol (1997) says that about $80 \%$ people use English while they are in business in Europe. Not only in Europe, it is also used in global business which is happened under the control of World Trade Organization (WTO).

\section{English in the Medium of Instruction}

It is used as the medium of instruction both in school and higher education. The worldwide estimation shows that those countries having English medium based education have been performing well. Regarding the evaluation of best education system, Pearson Education Group conducts researches per year. It's report of 2015/16 shows that the countries which give the high priority to English education have gained better ranks than others, no matter whether the countries are native or non-native. In the study, South Korea, Japan, Honkong, Switzerland, etc are in the respective rank. Same is the case in Nepal. As we observe the every year's SLC result, English medium based private schools are showing better performance than public school. We conclude that for better and quality education, English medium based instruction is necessary.Moreover, there are thousands of language centers which provide English language classes to the people for their wider communication.

\section{English in Publication and Media}

The best opportunity around the world for name, fame, money and mind is publication and media. It is supposed that without books and media no one can gain the information. The matter is not confined with publication and media only, the more important is the language which is used in them. Obviously, English language takes that place. Regarding the domination of English language in third-world book publication, Ashcroft, Griffiths and Tiffin (as cited in Expanding Horizon in English) declare that in India, half of the book titles are published in English, while only $2 \%$ of the population is literate in English. In addition to this, $1 / 3 \mathrm{rd}$. of the books are published in English all over the world.

The same domination of English is in media also. Media are the most powerful means of communication. Most of the famous TV channels, radio broadcastings, daily newspapers, 
weekly, fortnightly, monthlyand periodic journals, etc are in English. Crystal (3003) mentions that in the1990s the journal Linguistics Abstracts was reviewing the content of over 160 linguistics journals worldwide: nearly 70 per cent were published entirely in English. In the physical sciences the figure may reach 80 percent or more. Through media, people can listen, watch and learn English language wherever they are.

\section{English as a Lingua-franca}

As a lingua-franca, English language is used as a means of communication among bi- or multi-lingual speakers for different purposes all over the world. Crystal (2003) emphasizes that as there was no common language between/ among the bi- or multilingual speakers, the communication couldn't take place properly but as English takes that place, it becomes easy for all. Again, he declares that different sorts of pidgins are also used as lingua-franca but having limited functions, they can't cover the diverse forms of communication. As a lingua-franca, it is mainly used in international political activities, world-wide organizational transaction and trade and business around the world.

\section{English for Disseminating Culture, Heritage and Tradition}

Language shapes the culture and vice-versa. Language speaks the culture and helps to preserve it for a long time. English language has gained the world wide status due which it can carry the culture, tradition and heritage wherever it is spoken. As the concept of world Englishes developed, the gap among the speakers of inner circle, outer circle and expanding circle as Kachru sees( as cited in Crystal, 2003) has been already fulfilled. At the time of convergence those who learn English language, should learn the English culture also. But, as the concept of divergent is accepted, the concept of language learning gets changed which emphasizes on the English language learning in non-native speakers' own cultural context which obviously helps for the development of diverse culture all over the world. This is how English language learning becomes medium of relaying culture, tradition and heritage through different books, records, media, websites, visitors and so on.

Becoming English as a global language, it creates lots of hopes and waves of opportunities in the world. An individual can get bread and butter if he/ she is competent in English. Besides this, they can perceive the world easily since most of the sources of information are in English.

\section{English in Technology}

It is the age of technology without which its people can't survive as being human being in the world. Information and communication is entirely controlled by modern technology where as the technology is dominated by English language. So, without having the knowledge of 
English, nobody can handle the technology and be benefited from it. Computers, Internet, websites, mobile, laptop, etc are some of the examples of technology. But regarding the use of English in technology, Graddol (2006), says, It is often claimed that English dominates computers and the internet, and that those wishing to use either must first learn English. That may have been true in the early days of the technology, but lack of English is no longer the barrier it once was.

\section{English as a Global Language: Challenges}

There are thousands of languages and cultures all over different countries. As English has been used globally, the minorities languages and cultures have been extincted .Emphasizing on the demerit side of English, Crystal (2003) says that thousands of language have been lost and out of remaining 6000 languages, about $50 \%$ will be lost by next century. If it possibly happen, imagination of world diversity will be no more existed. In contrary, Graddol (2006) observes the situation of it from different angle. In his book he presented the fact that the no. of internet users by using English language were $51.3 \%$ in 2000 where as only $31 \%$ in 2005 . From these two estimations, it is understood that the future of English in one way is so brightful, on the other, the matter of worrisome.

English is the global language which speakers are scattered everywhere but not the first with respect to the numbers. It is Chinese language which has the largest numbers of speakers but limited within China only. But, the contemporary status and practices started by Chinese government show that it is going to challenge the status of English language no sooner than later.

Once there was the British imperialism, but in these days linguistic hegemony, especially of British and American English throughout the world. Though English language policy shifting from convergence to divergence and ensuring the existence of local languages and cultures, it is not the time to be sure and certain since the powerful languages are doing linguistic business for their own language development.

\section{Conclusion}

English is a global language. It connects the people from different linguistic backgrounds who reside within or across the nations to each other so that they could fulfill their needs. The way it is used and considered in different countries, its status is maintained as native, second, foreign, official, or international language. Whatever the forms and status, it is globally used for various purposes. Its people can get different opportunities since it has the high coverage and influential scopes in the different fields like; business, trading, education, communication, science and technology, media, computer, publication, internet, and so on. So, it is said that survival is impossible unless there is English language with each of us. 


\section{Global Language: Status, Scope and Challenges}

Growing use of it not only provides opportunities but also challenges as well. It affects the social, cultural, and linguistic diversity of the world. Many of the languages and cultures had already been died out and those which are existed are also bound to extinct in the near future. Some alternative languages have also been challenging its status recently, due which its speakers are slightly decreasing as some researches portrayed. So, it is so soon to predict its future whether it will be bless or curse for the world.

\section{References}

Broughton, G., Brumfit, C., Flavell , R., Hill, P., \& Pincas, A. (1980). Teach English as a foreign language $\left(2^{\text {nd }}\right.$. ed.). New York: Routledge.

Crystal, D. (2003). English as a global language ( $2^{\text {nd }}$. ed). New York: Cambridge University Press.

Euromonitor International Report. (2010). The benefits of English language for Individuals and Societies: Quantitative Indicators from Cameroon, Nigeria, Rwanda, Bangladesh and Pakistan.

Graddol, D. (1997). The future of English?. UK: The British Council. 